\title{
Regulation of early enzymes of ergosterol biosynthesis in Saccharomyces cerevisiae
}

\author{
Madeleine SERVOUSE and Francis KARST \\ Laboratoire de Biochimie et Génétique des Microorganismes, J.E.CNRS 034620, Université de Poitiers, \\ 40 avenue du Recteur Pineau, F-86022 Poitiers-Cedex, France
}

\begin{abstract}
In order to determine the regulation mechanisms of ergosterol biosynthesis in yeast, we developed growth conditions leading to high or limiting ergosterol levels in wild type and sterol-auxotrophic mutant strains. An excess of sterol is obtained in anaerobic sterol-supplemented cultures of mutant and wild type strains. A low sterol level is obtained in aerobic growth conditions in mutant strains cultured with optimal sterol supplementation and in wild type strain deprived of pantothenic acid, as well as in anaerobic cultures without sterol supplementation. Measurements of the specific activities of acetoacetyl-CoA thiolase, HMG-CoA (3-hydroxy-3-methylglutaryl-CoA) synthase and HMG-CoA reductase (the first three enzymes of the pathway), show that in cells deprived of ergosterol, acetoacetyl-CoA thiolase and HMG-CoA synthase are generally increased. In an excess of ergosterol, in anaerobiosis, the same enzymes are strongly decreased. A 5-10-fold decrease is observed for acetoacetyl-CoA thiolase and HMG-CoA synthase. In contrast, HMG-CoA reductase is only slightly affected by these conditions. These results show that ergosterol could regulate its own synthesis, at least partially, by repression of the first two enzymes of the pathway. Our results also show that exogenous sterols, even if strongly incorporated by auxotrophic mutant cells, cannot suppress enzyme activities in aerobic growth conditions. Measurement of specific enzyme activities in mutant cells also revealed that farnesyl pyrophosphate thwarts the enhancement of the activities of the two first enzymes.
\end{abstract}

\section{INTRODUCTION}

Extensive evidence indicates that in mammalian cells the enzyme HMG-CoA reductase functions as the primary regulatory site in cholesterol biosynthesis. Thus high levels of serum sterols in the form of low-density lipoprotein repress HMG-CoA reductase activity both by reducing enzyme synthesis as well as by shortening the half-life of the protein [1].

The major difficulty in studying the regulation of the ergosterol pathway in yeast is that under standard aerobic growth conditions, yeast synthesizes large amounts of ergosterol and does not incorporate significant amounts of exogenous sterol [2]. Under anaerobic growth conditions, yeast cells cannot synthesize sterol rings and the exogenously supplied sterols are used. Anaerobic cultures of yeast cells have therefore been used by several groups of workers to study the effect of sterol starvation or sterol feeding on endogenous sterol biosynthesis. It has been shown that the increase in ergosterol formation observed after shifting yeast cells from anaerobic to aerobic growth conditions is correlated with an increase in the specific activity of HMG-CoA reductase [3]. Trocha \& Sprinson [2] reported that the levels of acetoacetyl-CoA thiolase and HMG-CoA synthase are decreased by ergosterol in anaerobic yeast cells whereas HMG-CoA reductase is only slightly affected. Recently [4] it has been reported that squalene accumulation in anaerobically grown yeast cells is decreased 4-fold at high ergosterol supplementation $(100 \mathrm{mg} / \mathrm{l})$ in comparison with low level $(2 \mathrm{mg} / \mathrm{l})$, indicating thereby a regulation step before squalene synthesis.
An alternative route to manipulate the sterol level in yeast is to use ergosterol-auxotrophic mutant strains which require sterol supplementation in standard aerobic cultures. These auxotrophic mutants could also allow the determination of possible regulatory effects due to precursor molecules of ergosterol accumulated as a result of the enzymic lesion. Auxotrophic mutants blocked in various steps of the ergosterol pathway have been isolated by our group [5].

First we determined the growth conditions necessary for obtaining cells that have either a high or a low sterol level. We then measured the specific activities of the first three enzymes of ergosterol biosynthesis, acetoacetylCoA thiolase, HMG-CoA synthase and HMG-CoA reductase in cell-free supernatants of wild type and mutant strains according to their ergosterol level.

The results show that acetoacetyl-CoA thiolase activity presents the greatest change according to the culture conditions, HMG-CoA reductase activity being only slightly modified.

\section{EXPERIMENTAL PROCEDURES}

\section{Growth conditions}

All strains used were derived from Saccharomyces cerevisiae FL 100 (A.T.C.C. 28383), haploid, a mating type, or from an isogenic strain FL 200 (A.T.C.C. 32119), haploid, $\alpha$ mating type.

The complete medium used consisted of (per litre): yeast extract (Biokar), $10 \mathrm{~g}$; Peptone Pepsique de Viande (Biokar), $10 \mathrm{~g}$; glucose, $20 \mathrm{~g}$. Ergosterol, cholesterol, oleic acid and DL-mevalonic acid (lactone form) were

Abbreviation used: HMG-CoA, 3-hydroxy-3-methylglutaryl-CoA.

Vol. 240 
supplied by dilution of stock solutions in a mixture of Tergitol NP-40/ethanol (1:1, v/v).

Aerobic growth was carried out in Erlenmeyer flasks with continuous shaking at $28^{\circ} \mathrm{C}$. Anaerobic growth was started by inoculating yeast cells in 1 litre volumetric flasks, almost completely filled with the growth medium and covered with liquid paraffin $(2-3 \mathrm{~cm})$.

Minimal medium is a synthetic medium, having the same composition as yeast nitrogen base without amino acids and $\left(\mathrm{NH}_{4}\right)_{2} \mathrm{SO}_{4}$ (DIFCO), but without calcium pantothenate. Glucose $(10 \mathrm{~g} / 1)$ was the energy source and casein hydrolysate $(5 \mathrm{~g} / \mathrm{l})$ was the sole source of nitrogen.

Generation times were calculated from readings taken during the exponential phase.

\section{Dry weight determination}

Dry weight was obtained by filtration of an aliquot of cell suspension on a preweighed membrane filter (pore size $0.45 \mu \mathrm{m}$ ). The filter was dried for $2 \mathrm{~h}$ at $120^{\circ} \mathrm{C}$ before weight determination.

\section{Determination of crude ergosterol in non-saponifiable lipids}

Cells were collected by centrifugation and washed three times with $0.1 \mathrm{M}$-potassium phosphate buffer, $\mathrm{pH} 7.4$, containing $0.2 \%$ Tergitol NP-40. The cell pellet was saponified with methanolic $40 \%$ (w/v) $\mathrm{KOH}$ at $95^{\circ} \mathrm{C}$ for $60 \mathrm{~min}$ and non-saponifiable lipids were extracted with n-heptane [6]. The u.v. spectrum of the desiccated heptanic solution only showed peaks at 293, 281.5 and $272 \mathrm{~nm}$, typical of sterols with 5,7-diene system. The amount of 'ergosterol' was determined from the maximum absorbance at $281.5 \mathrm{~nm}$ $\left(A_{281.5}^{1 \%}=290\right.$ for ergosterol).

\section{Enzyme assays}

After overnight growth in $200 \mathrm{ml}$ of medium, cells were harvested by centrifugation, washed once with ice-cold $0.1 \mathrm{M}$-phosphate buffer ( $\mathrm{pH}$ 7.4) containing $0.2 \%$ Tergitol NP-40 and twice with the same buffer without detergent. Cells were then suspended in $1 \mathrm{ml}$ of homogenization buffer, glass beads $(1 \mathrm{ml}, 0.45 \mathrm{~mm}$ diameter) were added and the cells were disrupted by vortex-mixing for $3 \mathrm{~min}$. The suspension of broken cells was pipetted from the glass beads and the beads were rinsed twice with buffer to give a total volume of $3 \mathrm{ml}$. The homogenate was centrifuged at $1000 \mathrm{~g}$ for $5 \mathrm{~min}$ and the supernatant was again centrifuged at $8000 \mathrm{~g}$ for $15 \mathrm{~min}$.

Acetoacetyl-CoA thiolase was measured as described by Stewart and Rudney [7]. Homogenization buffer was $0.15 \mathrm{M}$-Tris $/ \mathrm{HCl}$, pH 8.2, containing $0.5 \mathrm{~mm}$-dithiothreitol and 1 mm-EDTA. The sample and reference cells of a Beckman DB spectrophotometer contained: $0.7 \mathrm{ml}$ of homogenization buffer, $0.143 \mathrm{~mm}$-acetoacetyl$\mathrm{CoA}$ and $50-300 \mu \mathrm{g}$ of $8000 \mathrm{~g}$ supernatant protein. The reaction was initiated by adding $0.143 \mathrm{~mm}-\mathrm{CoA}$ to the sample cell. The disappearance of acetoacetyl-CoA was recorded at $300 \mathrm{~nm}$. For each determination, three to five assays were done with increasing protein concentration. The rate of reaction was linear during $2 \mathrm{~min}$ and was proportional to protein concentration within the range $25-300 \mu \mathrm{g}$ of protein. Specific activity is expressed in $\mathrm{nmol}$ of acetoacetyl-CoA/min per $\mathrm{mg}$ of protein.

HMG-CoA synthase was measured as described by
Table 1. Gene-enzyme relations in ergosterol biosynthesis in yeast

Enzyme lesions were determined by assays in vitro [5,9]. Loci erg 2 to erg6, not shown here, have been isolated by nystatin resistance, and correspond to blocks in late stages of ergosterol biosynthesis [6,12].

\begin{tabular}{|c|c|}
\hline Gene & Enzyme \\
\hline $\operatorname{erg} 10 A, B$ & $\begin{array}{l}\text { Acetoacetyl-CoA } \\
\text { thiolase }\end{array}$ \\
\hline $\operatorname{erg} 11, \operatorname{erg} 13$ & HMG-CoA synthase \\
\hline $\operatorname{erg} 12$ & Mevalonate kinase \\
\hline erg 8 & $\begin{array}{l}\text { Phosphomevalonate } \\
\text { kinase }\end{array}$ \\
\hline $\operatorname{erg} 19$ & $\begin{array}{l}\text { Pyrophosphomevalonate } \\
\text { decarboxylase }\end{array}$ \\
\hline $\operatorname{erg} 9$ & Squalene synthetase \\
\hline $\operatorname{erg} 1, \operatorname{erg} 18, \operatorname{erg} 14$ & Squalene epoxidase \\
\hline $\operatorname{erg} 7, \operatorname{erg} 17$ & $\begin{array}{l}\text { Oxidosqualene: } \\
\text { lanosterol cyclase }\end{array}$ \\
\hline $\operatorname{erg} 16$ & $\begin{array}{l}\text { Lanosterol } \\
\text { demethylase }\end{array}$ \\
\hline
\end{tabular}

Stewart and Rudney [7]. The same buffer as above was used. The sample cell contained $0.7 \mathrm{ml}$ of buffer, $0.036 \mathrm{~mm}$-acetoacetyl-CoA and $25-300 \mu \mathrm{g}$ of protein. Endogenous activity was measured for $2 \mathrm{~min}$, then $0.143 \mathrm{~mm}$-acetyl-CoA was added and the $A_{300}$ was again recorded. The difference between the rates corresponds to HMG-CoA synthase activity. For each determination, three to five assays were done with increasing protein concentration. The rate of reaction was linear for $1-3 \mathrm{~min}$ and proportional to protein concentration within the range $25-300 \mu \mathrm{g}$ of protein. Specific activity is expressed in nmol of acetoacetyl-CoA/min per $\mathrm{mg}$ of protein.

The incubation temperature was $25^{\circ} \mathrm{C}$.

HMG-CoA reductase was measured as described by Quain and Haslam [8]. Cells were broken in $0.1 \mathrm{M}-$ phosphate buffer, pH 7.0, containing 1 mM-EDTA, $10 \mathrm{~mm}$-dithiothreitol and $0.5 \%$ Triton $\mathrm{X}-100$. The homogenate was incubated for $60 \mathrm{~min}$ at $0{ }^{\circ} \mathrm{C}$, then centrifuged at $1000 \mathrm{~g}$ for $5 \mathrm{~min}$, and the resulting supernatant was again centrifuged at $8000 \mathrm{~g}$ for $15 \mathrm{~min}$.

The reaction mixture contained, in $0.7 \mathrm{ml}$ of homogenization buffer containing the detergent, $0.15 \mathrm{mM}$ NADPH and $50-300 \mu \mathrm{g}$ of $8000 \mathrm{~g}$ supernatant protein. Endogenous oxidation of NADPH was recorded at $340 \mathrm{~nm}$, with a Perkin-Elmer $550 \mathrm{~S}$ spectrophotometer, before starting the reaction with $0.086 \mathrm{~mm}-\mathrm{HMG}-\mathrm{CoA}$. Specific activities were calculated from the slopes of the curves obtained by using increasing protein concentrations and are expressed in nmol NADPH oxidized/min per $\mathrm{mg}$ of protein. The reaction was done at $30^{\circ} \mathrm{C}$. Quain and Haslam have shown that about $84 \%$ of the total HMG-CoA reductase activity is recovered in the $8000 \mathrm{~g}$ supernatant [8].

Protein concentration was determined by the biuret method with serum albumin as standard.

\section{RESULTS}

The sterol-auxotrophic mutant strains have been isolated as thermosensitive clones. Thermosensitivity means that the mutant strains require a sterol supple- 
Table 2. Effect of ergosterol supplementation on ergosterol level in wild type and mutant strains

Crude ergosterol content was determined as described under 'Experimental procedures' and is expressed as \% of cell dry weight \pm S.D. (number of independent experiments). Aerobic growth: cells were grown overnight in complete medium at $28^{\circ} \mathrm{C}$ with shaking and harvested during exponential growth phase. Anaerobic growth: complete medium was supplemented with oleic acid $(50 \mathrm{mg} / \mathrm{l})$ and ergosterol as indicated. Growth of mutant strain erg 11 was only obtained in medium supplemented with mevalonic acid (lactone form, $600 \mathrm{mg} / \mathrm{l}$ ) in addition to ergosterol. Inoculum was $0.005 \mathrm{mg} \mathrm{dry} \mathrm{wt./ml.} \mathrm{Cultures} \mathrm{were} \mathrm{left}$ to grow for $72 \mathrm{~h}$ at $28^{\circ} \mathrm{C}$. Growth yields ranged from 1.1 for mutant strains to 1.3 for wild type strain (mg dry wt./ml). Cells of wild type strain cultured anaerobically without any supplement contained $0.11 \%$ ergosterol: growth yield was $0.45 \mathrm{mg} / \mathrm{ml}$ in this condition.

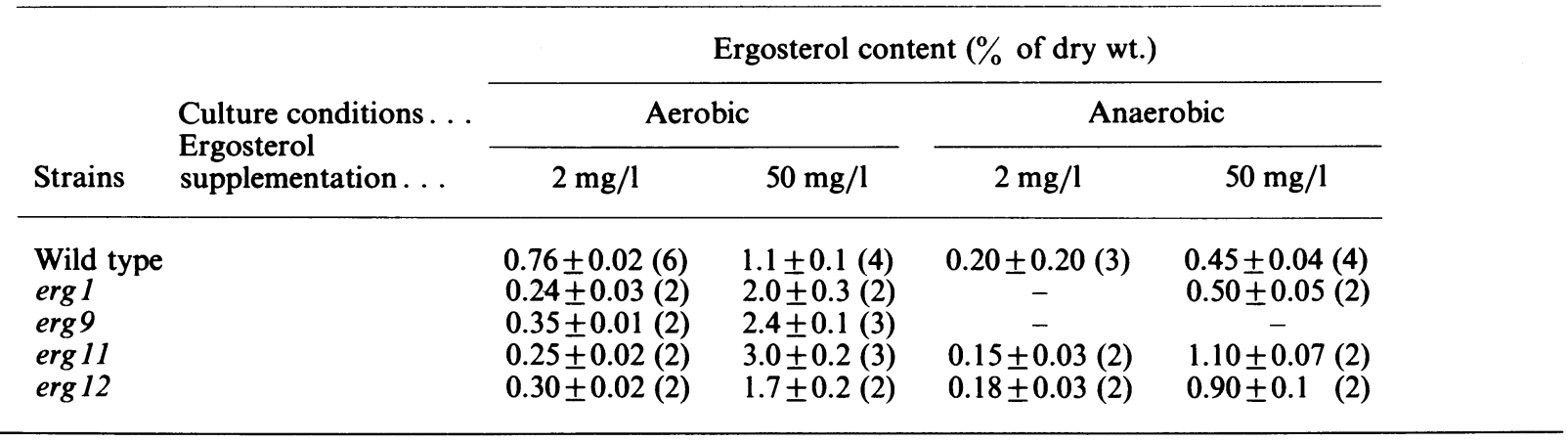

mentation at a low temperature $\left(26-30^{\circ} \mathrm{C}\right)$ but are generally unable to grow at a high temperature $\left(36^{\circ} \mathrm{C}\right)$ even in the presence of sterol. Selection procedures and genetic analysis as well as the determination of the enzymic blocks have been described [5,9]. Table 1 summarizes the gene-enzyme relations. In assays in vitro at permissive temperature, it is worth noting that no enzyme activity is generally detectable in a corresponding mutant, except in the erg $10 \mathrm{~A}$ mutant strain which presents a very small acetoacetyl-CoA thiolase activity [9].

\section{Ergosterol content in wild type and mutant strains in response to ergosterol supplementation}

Under aerobic standard conditions at $28^{\circ} \mathrm{C}$, sterol auxotrophic mutant strains present optimal growth at ergosterol supplementation of $2 \mathrm{mg} / 1$ [10]. Under such conditions, sterol auxotrophs show an ergosterol level of about $0.3 \%$ of dry cell wt. With high ergosterol supplementation $(50 \mathrm{mg} / 1)$, the ergosterol level of the cells is enhanced by $6-10$-fold $(\operatorname{erg} 1, \operatorname{erg} 9, \operatorname{erg} 11$ and erg 12) (Table 2).

The ergosterol content of the wild type strain is $0.8 \%$ in the absence of exogenous sterol or in the presence of $2 \mathrm{mg}$ of ergosterol/1. If ergosterol supplementation is raised to $50 \mathrm{mg} / \mathrm{l}$, the content of cells is increased to a value of about $1.1 \%$. The wild type strain is therefore relatively impermeable to exogenous sterol in areobic growth, whereas auxotrophic mutants are generally highly permeable to sterols.

Mutant strains, with an ergosterol level of about $0.3 \%$, present optimal growth. But it was not possible to obtain a significant decrease in this value by sterol starvation since the generation time increases dramatically and growth stops before an appreciable ergosterol decrease occurs. Hence it can be assumed that this value of $0.3 \%$ ergosterol level is sufficient but probably minimal for aerobic yeast growth. However it should be noted that the generation time of mutant strains, even at optimal sterol supplementation, is $50 \%$ higher than in wild type strain (results not shown).
Yeast cells require ergosterol and oleic acid supplementation in anaerobic growth conditions, since fatty acid desaturation and some steps of ergosterol biosynthesis are catalysed by mixed-function oxygenases. In order to obtain sterol starvation and uptake of exogenously provided sterol in the wild type strain, yeast was grown in anaerobiosis with oleic acid supplementation as described under 'Experimental procedures'. With an ergosterol supplementation of $2 \mathrm{mg} / 1$, an ergosterol content near $0.2 \%$ is observed in mutant as well as in wild type strains (Table 2). Calculation shows that under these growth conditions all the exogenous ergosterol has been incorporated into the cells. With an excess of ergosterol $(50 \mathrm{mg} / 1)$, the sterol content is $0.45 \%$ in wild type strain and ranges from 0.5 to $1.0 \%$ in mutant strains. However this increase in sterol content does not

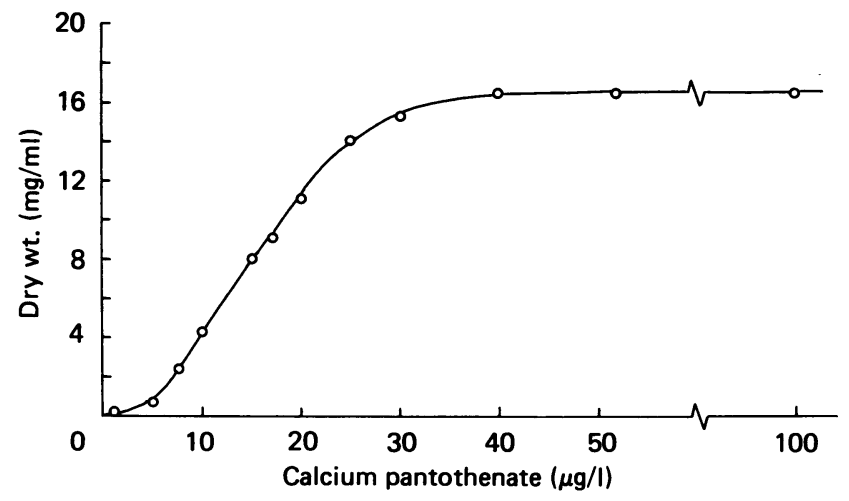

Fig. 1. Effect of pantothenic acid on wild type strain growth

Growth medium had the same composition as yeast nitrogen base without amino acids and $\left(\mathrm{NH}_{4}\right)_{2} \mathrm{SO}_{4}$ (Difco), but without calcium pantothenate. Casein hydrolysate $(5 \mathrm{mg} / \mathrm{l})$ was the sole source of nitrogen and glucose $(10 \mathrm{mg} / \mathrm{l})$ was the carbon source. Inoculum was $2 \mathrm{mg} / \mathrm{l}$ (dry cell wt). Growth was monitored by dry weight determination in post-exponential growth phase. 
Table 3. Effect of ergosterol supplementation [ $2 \mathrm{mg} / \mathrm{l}$ (low) and $50 \mathrm{mg} / \mathrm{l}$ (high)] on specific activities of acetoacetyl-CoA thiolase, HMG-CoA synthase and HMG-CoA reductase in aerobically grown wild type and mutant strains

Strains were grown in a complete medium with ergosterol $(2 \mathrm{mg} / 1$ or $50 \mathrm{mg} / \mathrm{l})$ and collected during the exponential growth phase. The enzyme assays were performed as described in the Experimental section. The results are expressed \pm S.D. (number of independent experiments).

\begin{tabular}{|c|c|c|c|}
\hline \multirow[b]{2}{*}{ Strains } & \multicolumn{3}{|c|}{$\begin{array}{l}\text { Enzyme specific activities } \\
\text { (nmol/min per } \mathrm{mg} \text { of protein) }\end{array}$} \\
\hline & $\begin{array}{c}\text { Acetoacetyl-CoA } \\
\text { thiolase }\end{array}$ & $\begin{array}{l}\text { HMG-CoA } \\
\text { synthase }\end{array}$ & $\begin{array}{l}\text { HMG-CoA } \\
\text { reductase }\end{array}$ \\
\hline \multicolumn{4}{|c|}{ Low ergosterol supplementation ( $2 \mathrm{mg} / \mathrm{l})$} \\
\hline FL 100 (wild type) & $140 \pm 20(12)$ & $22 \pm 6(8)$ & $5.5 \pm 1.4(7)$ \\
\hline $\operatorname{erg} 16$ & $336 \pm 14(2)$ & $48 \pm 2(2)$ & $6.0 \pm 0.1(2)$ \\
\hline $\operatorname{erg} 7$ & $238 \pm 14(2)$ & $20 \pm 4(2)$ & $5.0 \pm 1.4(3)$ \\
\hline erg 1 & $252 \pm 51(5)$ & $35 \pm 9(5)$ & $5.0 \pm 1.1(4)$ \\
\hline $\operatorname{erg} 9$ & $126 \pm 28(3)$ & $20 \pm 4(3)$ & $4.4 \pm 1.6(2)$ \\
\hline $\operatorname{erg} 8$ & $336 \pm 42(3)$ & $48 \pm 6(3)$ & $5.5 \pm 1.6(2)$ \\
\hline $\operatorname{erg} 12$ & $294 \pm 56(4)$ & $33 \pm 11(3)$ & $4.4 \pm 1.4(3)$ \\
\hline erg 11 & $322 \pm 42(4)$ & 0 & $8.2 \pm 1.3(5)$ \\
\hline $\operatorname{erg} 10 B$ & 0 & $22 \pm 2(2)$ & $10.0 \pm 0.1(2)$ \\
\hline erg6 (nys R) & $154 \pm 10(2)$ & $22 \pm 1(2)$ & $5.0 \pm 1.1(2)$ \\
\hline \multicolumn{4}{|c|}{ High ergosterol supplementation $(50 \mathrm{mg} / \mathrm{l})$} \\
\hline FL 100 (wild type) & $140 \pm 18(2)$ & $20 \pm 3(2)$ & $5.0 \pm 0.7(2)$ \\
\hline $\operatorname{erg} 1$ & $266 \pm 28(2)$ & $40 \pm 4(2)$ & $4.4 \pm 0.7(2)$ \\
\hline erg 12 & $308 \pm 42(2)$ & $35 \pm 9(2)$ & $3.3 \pm 0.1$ (2) \\
\hline $\operatorname{erg} 11$ & $322 \pm 28(2)$ & 0 & $8.2 \pm 1.4(2)$ \\
\hline
\end{tabular}

improve the cell yield, indicating that the low ergosterol value of $0.2 \%$ is not growth-limiting. Growth of wild type strain without any supplementation of both ergosterol and oleic acid leads to a 3-fold lowering of the cell yield. The cellular content of ergosterol is in this case lowered to $0.1 \%$ (Table 2 legend).

It may be argued that the metabolism of cells grown in the absence of oxygen is very different from that of aerobically grown cells. We therefore attempted to obtain aerobic growth conditions leading to a lowering in the ergosterol level of wild type strains. Hosono and Aida [11] reported that pantothenic acid deficient cells contain only a quarter of ergosterol compared with normal cells. We tested wild type strain growth yield as a function of pantothenic acid concentration in a minimal medium. Fig 1 shows that a linear relationship is observed in the range $5-20 \mu \mathrm{g} / 1$, saturation being obtained from $40 \mu \mathrm{g} / 1$. A 3-fold lowered ergosterol content $(0.23 \%)$ is in fact obtained in cells growing with a limited amount of pantothenic acid $(15 \mu \mathrm{g} / 1)$ whereas the normal value of $0.8 \%$ ergosterol level was obtained with saturating pantothenic acid concentration as in a standard minimal medium (see Table 5).

\section{Specific activities of acetoacetyl-CoA thiolase, HMG-CoA synthase and HMG-CoA reductase in wild type and mutant strains}

Enzymic activities were first measured in cell-free supernatants of cells grown in a complete medium containing an optimal amount $(2 \mathrm{mg} / 1)$ of ergosterol. The results are shown in Table 3. Acetoacetyl-CoA thiolase generally presents a 2-fold enhancement in mutant strains in comparison with the wild type strain, except erg 9, blocked in squalene synthetase. For HMG-CoA synthase, similar increment values are observed in mutant strains, with the exception of erg9, but also of erg 7 blocked in lanosterol: oxidosqualene cyclase and erg $10 \mathrm{~B}$ blocked in acetoacetyl-CoA thiolase. HMG-CoA reductase is generally not enhanced in mutant strains. An increase is only observed in mutant strains, $\operatorname{erg} 10 B$ and $\operatorname{erg} 11$, blocked in the first two steps of the pathway.

In the same conditions, we also measured the enzymic activities of mutant erg6, which was blocked in C-24-sterol methyltransferase [12] and thus unable to synthesize ergosterol. This mutant, selected by - its nystatin-resistance, is not auxotrophic for ergosterol, since endogenously biosynthesized sterols (zymosterol and cholesta-5,7,22,24-tetraen-3 $\beta$-ol) satisfy cellular physiology. Table 3 shows that enzyme levels are identical with those of the wild type strain.

Enzymic activities were then measured in mutant strains erg 11 (HMG-CoA synthase), erg 12 (mevalonate kinase) and erg 1 (squalene epoxidase) after growth in the presence of an excess of ergosterol $(50 \mathrm{mg} / 1)$.

In these conditions, the specific activities of the three enzymes (Table 3 ) do not present any important changes in comparison with the preceding conditions, although ergosterol cell content is increased 6-10-fold.

Anaerobic growth allows the study of the relationship between low sterol content and enzymic activities without a mutant background. Wild type strain was grown under such conditions either with a low $(2 \mathrm{mg} / 1)$ or with a high $(50 \mathrm{mg} / 1)$ ergosterol supplementation. Table 4 shows that the enzyme activities are strongly lowered in comparison with those of aerobic growth: 2-fold for HMG-CoA reductase, 3-fold for $\mathrm{HMG}-\mathrm{CoA}$ synthase and 4-5-fold for acetoacetyl-CoA thiolase, whatever the sterol level of the cells, 0.2 or $0.45 \%$.

Enzyme activities in mutant strain erg 1, grown under 
Table 4. Specific activities of early sterol biosynthetic enzymes in anaerobically grown cells: effect of sterol supplementation

A complete medium was supplemented or not with oleic acid $(50 \mathrm{mg} / \mathrm{l})$, ergosterol $(2$ or $50 \mathrm{mg} / \mathrm{l})$ or cholesterol $(50 \mathrm{mg} / \mathrm{l})$. Inoculum and other growth conditions are the same as in Table 2.

\begin{tabular}{|c|c|c|c|c|}
\hline \multirow[b]{2}{*}{ Supplements } & \multirow[b]{2}{*}{ Strains } & \multicolumn{3}{|c|}{$\begin{array}{c}\text { Enzyme specific activities } \\
\text { (nmol/min per mg of protein) }\end{array}$} \\
\hline & & $\begin{array}{l}\text { Acetoacetyl-CoA } \\
\text { thiolase }\end{array}$ & $\begin{array}{l}\text { HMG-CoA } \\
\text { synthase }\end{array}$ & $\begin{array}{l}\mathrm{HMG}-\mathrm{CoA} \\
\text { reductase }\end{array}$ \\
\hline $\begin{array}{l}\text { Oleic acid }+ \\
\quad \text { ergosterol }(2 \mathrm{mg} / \mathrm{l})\end{array}$ & $\begin{array}{l}\text { FL } 100 \\
\text { erg } 1\end{array}$ & $\begin{array}{l}34 \pm 5(2) \\
42 \pm 7(2)\end{array}$ & $\begin{array}{r}7 \pm 2(2) \\
14 \pm 2(2)\end{array}$ & $\begin{array}{l}2.8 \pm 0.3(3) \\
2.5 \pm 0.1(2)\end{array}$ \\
\hline $\begin{array}{l}\text { Oleic acid }+ \\
\quad \text { ergosterol }(50 \mathrm{mg} / \mathrm{l})\end{array}$ & $\begin{array}{l}\text { FL } 100 \\
\text { erg } 1\end{array}$ & $\begin{array}{l}28 \pm 7(2) \\
31 \pm 5(2)\end{array}$ & $\begin{array}{r}6 \pm 2(2) \\
10 \pm 2(2)\end{array}$ & $\begin{array}{l}2.5 \pm 0.1(2) \\
2.8 \pm 0.4(2)\end{array}$ \\
\hline $\begin{array}{l}\text { Oleic acid }+ \\
\quad \text { cholesterol }(50 \mathrm{mg} / \mathrm{l}) \\
\text { None }\end{array}$ & $\begin{array}{l}\text { FL } 100 \\
\text { erg } 1 \\
\text { FL100 }\end{array}$ & $\begin{array}{c}45 \pm 7(2) \\
36 \pm 5(2) \\
280 \pm 24(3)\end{array}$ & $\begin{array}{r}9 \pm 2(2) \\
15 \pm 2(2) \\
33 \pm 8(3)\end{array}$ & $\begin{array}{c}2.3 \pm 0.5(2) \\
2.4 \pm 0.5(2) \\
\text { Not measurable }\end{array}$ \\
\hline
\end{tabular}

Table 5. Effect of pantothenic acid starvation on ergosterol level and early sterol biosynthetic enzymes in aerobically grown wild type strain

The growth medium used was the same as in Fig. 1. Cells were collected during the exponential phase of growth. Inoculum was $0.002 \mathrm{mg}$ cell dry wt. $/ \mathrm{ml}$.

\begin{tabular}{lcccc}
\hline & & \multicolumn{3}{c}{$\begin{array}{c}\text { Enzyme specific activities } \\
(\text { nmol/min per mg of protein) }\end{array}$} \\
\cline { 3 - 4 } $\begin{array}{c}\text { Pantothenic } \\
\text { acid } \\
(\mathrm{mg} / \mathrm{l})\end{array}$ & $\begin{array}{c}\text { Ergosterol } \\
\text { level } \\
(\% \text { dry wt. })\end{array}$ & $\begin{array}{c}\text { Acetoacetyl-CoA } \\
\text { thiolase }\end{array}$ & $\begin{array}{c}\text { HMG-CoA } \\
\text { synthase }\end{array}$ & $\begin{array}{c}\text { HMG-CoA } \\
\text { reductase }\end{array}$ \\
\hline 0.015 & $0.23 \pm 0.02(4)$ & $322 \pm 56(4)$ & $40 \pm 6(3)$ & $6.6 \pm 1.0(2)$ \\
0.020 & $0.28(1)$ & - & - & - \\
0.025 & $0.58(1)$ & - & - & - \\
4 & $0.78 \pm 0.03(3)$ & $140 \pm 28(3)$ & $22 \pm 6(2)$ & $5.5 \pm 1.0(2)$ \\
\hline
\end{tabular}

the same two anaerobic conditions, were then measured (Table 4). Specific activities quite similar to those of the wild type strain are observed. It is worth noting that the acetoacetyl-CoA thiolase activity of $\operatorname{erg} 1$ is lowered 6-8-fold in comparison with that in aerobic growth.

As ergosterol was not significantly growth-limiting, even at a concentration of $2 \mathrm{mg} / 1$, the wild type strain was grown anaerobically without both ergosterol and oleic acid supplements. In these conditions, acetoacetylCoA thiolase and HMG-CoA synthase are respectively increased 9- and 5-fold, in comparison with the preceding supplemented medium (Table 4). HMG-CoA reductase activity is not measurable under these growth conditions.

The ergosterol content of the wild type strain is reduced 3-fold by pantothenic acid deprivation, and then it becomes very similar to that of mutant strains growing with a low amount of ergosterol. Enzyme measurements in cell-free extracts of wild type strain grown in a pantothenic acid-deficient medium, are shown in Table 5. The results show that acetoacetyl-CoA thiolase and HMG-CoA synthase are increased 2-fold whereas HMG-CoA reductase does not present a significant change. If culture medium contains an excess of pantothenic acid, the ergosterol level as well as the enzyme activities are those commonly observed in wild type aerobically grown cells.

\section{DISCUSSION}

Auxotrophic mutants are generally powerful tools to study fine regulation of biosynthetic pathways [13]. Depression or activation of enzyme activities due to starvation of the end product may be observed, but the influence of biosynthetic intermediates may also be displayed in mutant strains.

To understand the regulation mechanisms of the ergosterol biosynthetic pathway in yeast, we first measured acetoacetyl-CoA thiolase, HMG-CoA synthase and HMG-CoA reductase activities in cell-free extracts of mutant strains grown in optimal conditions, then we studied enzyme activities related to the ergosterol levels of mutant and wild type strains.

The comparison of enzyme activities in mutant and wild type strains grown under optimal conditions (Table 3) shows that acetoacetyl-CoA thiolase is generally enhanced 2-fold in mutant strains, with the exception of the $\operatorname{erg} 9$ mutant strain accumulating farnesyl pyrophosphate. HMG-CoA synthase activity is increased 
1.5-2-fold in mutants with high thiolase activity, except erg 7 blocked in oxidosqualene: lanosterol cyclase. In the erg $10 B$ mutant strain deficient in acetoacetyl-CoA thiolase, there is no increase in HMG-CoA synthase activity. These results suggest that the rise in HMG-CoA synthase must be linked to the increase in acetoacetylCoA thiolase. Thus in $\operatorname{erg} 9$, the only mutant strain without thiolase enhancement, HMG-CoA synthase is not increased. This observation assumes that thiolase and synthase activities might be regulated by the same mechanism. Moreover it may be pointed out that farnesyl pyrophosphate, placed at the main branch point of the sterol pathway, might repress the first enzymes, thus accounting for non-induced enzymes in erg 9 mutant strain.

Another important observation is that HMG-CoA reductase activity is only increased in the mutant strains erg $10 B$ and erg 11 blocked before mevalonic acid synthesis, which might mean that HMG-CoA reductase activity is regulated by the mevalonic acid pool.

All these results also strongly suggest that ergosterol may play a role in the regulation of its biosynthesis, in particular by regulating acetoacetyl-CoA thiolase and HMG-CoA synthase rather than HMG-CoA reductase. In fact, when mutant strains are grown with optimal sterol supplementation, the ergosterol level is $0.3 \%$ rather than $0.8 \%$ in wild type strain and in this condition, thiolase and synthase activities are increased, but not HMG-CoA reductase. In wild type strain with a low ergosterol level $(0.23 \%)$ due to pantothenic acid deprivation, thiolase and synthase are again 2-fold increased, whereas HMG-CoA reductase is not. Morever, anaerobic growth of wild type cells without oleic acid and ergosterol supplementation stops when the ergosterol level is $0.1 \%$ (Table 2), the lowest concentration consistent with membrane integrity [14]. Thiolase and synthase of these cells are still increased 1.5-2-fold. In these conditions, however, HMG-CoA reductase activity is not detectable in our assay in vitro. That might be the consequence of unsaturated fatty acid and sterol starvation, since reductase activity is a membrane-bound enzyme.

From these observations it can be concluded that ergosterol starvation induces thiolase and synthase activities. Conversely, ergosterol excess would repress the same enzyme activities. In fact, in anaerobic cultures of wild type and mutant strains with ergosterol excess, thiolase and synthase activities are strongly reduced. A 5 -fold decrease is observed in wild type strain and a 6-8-fold decrease in mutant erg 1, in comparison with their respective aerobic growths (Tables 3 and 4).

Enzyme depression is very likely due to reduced enzyme synthesis, since we and Trocha and Sprinson [2] have been unable to detect feedback inhibition by ergosterol in vitro.

However, there is no direct relationship between the ergosterol level in the cell and the first two ergosterol biosynthetic enzyme activities. Indeed enzyme activities from mutant strains with a high ergosterol content (up to $3 \%$ : Table 2) remain increased whereas in anaerobiosis, the same enzymes from cells with a low ergosterol level $(0.2 \%)$ are strongly depressed.

One way to explain mutant behaviour in aerobiosis is to argue that the regulatory molecule is an ergosterol precursor and not ergosterol itself. Thus the erg 16 ergosterol auxotroph, blocked in the lanosterol demeth- ylation steps, displays induced enzyme activities, whereas the erg 6 mutant strain devoid of C-24-sterol methyltransferase displays enzyme activities equal to those of the wild type strain. Therefore the regulatory molecule would be an intermediate linking lanosterol with cholesta-5,7,22,24-tetraen-3 $\beta$-ol.

Nevertheless, this hypothesis may not account for repressed activities in anaerobiosis since the wild type strain and mutant strains cannot synthesize demethylsterols in the absence of oxygen.

Another assumption may be that ergosterol itself or any other demethylsterol satisfying cellular physiology would regulate enzyme activities, but sterol molecules taken up from the medium by auxotrophic mutant strains in aerobiosis cannot enter the site to exert regulatory functions and remain associated with membranous structures. In contrast, in anaerobically grown cells where membranous systems are poorly developed, sterol molecules (ergosterol or cholesterol: Table 4) could enter the cell nucleus and repress enzyme synthesis. Indeed in anaerobic cultures cellular sterol needs are feeble since cells with $0.2 \%$ ergosterol level are not deprived of sterol. Their enzyme activities might therefore be repressed by an excess of free sterol. Enzyme increase would be obtained only after sterol starvation (ergosterol level $0.1 \%$ ).

Recently Pinto et al. [4] have shown that ergosterol lowers the squalene level in anaerobically grown cells, pointing to the regulatory function of ergosterol. The authors suggest that ergosterol acts as a feedback agent of HMG-CoA reductase. Our results from anaerobic cultures indicate that ergosterol may repress acetoacetylCoA thiolase and, but at a lower stage, HMG-CoA synthase and HMG-CoA reductase.

An alternative route to determine ergosterol regulation in yeast is to construct strains with enhanced enzyme activities due to the isolation of structural genes on multicopy plasmids. Two genes have been amplified at the present time, acetoacetyl-CoA thiolase [15] and HMG-CoA reductase [16]. Strains bearing these genes on multicopy plasmids show a 10 -fold increase in the specific activity of the corresponding enzymes. Yet an increase in the ergosterol level was not obtained in cells with amplified thiolase activity nor reported in cells with amplified HMG-CoA reductase activity.

We thank R. Defaye, M. Guilloton and I. Razagui for help in editing this manuscript. This work was supported by grant no. $81 / \mathrm{C} / 13081$ from Ministere de la Recherche et de la Technologie.

\section{REFERENCES}

1. Brown, M. S. \& Goldstein, J. L. (1980) J. Lipid Res. 21, 505-517

2. Trocha, P. J. \& Sprinson, D. B. (1976) Arch. Biochem. Biophys. 174, 45-51

3. Boll, M., Lowel, M., Still, J. \& Berndt, J. (1975) Eur. J. Biochem. 54, 435-444

4. Pinto, W. J., Lozano, R. \& Nes, W. R. (1985) Biochim. Biophys. Acta 836, 89-95

5. Karst, F. \& Lacroute, F. (1977) Mol. Gen. Genet. 154, 269-277

6. Molzahn, S. W. \& Woods, R. A. (1972) J. Gen. Microbiol. 72, 339-348 
7. Stewart, P. F. \& Rudney, H. (1966) J. Biol. Chem. 241, 1212-1221

8. Quain, D. E. \& Haslam, J. M. (1979) J. Gen. Microbiol. 111, 343-351

9. Servouse, M., Mons, N., Baillargeat, J. L. \& Karst, F. (1984) Biochem. Biophys. Res. Commun. 123, 424 430

10. Karst, F. \& Lacroute, F. (1974) Biochem. Biophys. Res. Commun. 59, 370-376

11. Hosono, K. \& Aida, K. (1974) J. Gen. Appl. Microbiol. 20, 47-58

Received 24 March 1986/2 July 1986; accepted 5 August 1986
12. Barton, D. H. R., Corrie, J. E. T., Widdowson, D. A., Bard, M. \& Woods, R. A. (1974) J. Chem. Soc. Perkin Trans. I 30, 1326-1333

13. Loison, G., Losson, R. \& Lacroute, F. (1980) Curr. Genet. 2, 39-44

14. Aries, V. \& Kirsop, B. H. (1978) J. Inst. Brew. 84, 118-122

15. Gloeckler, R., Dequin, S. Boutelet, F., Moll, M., Servouse, M. \& Karst, F. (1984) Proc. Int. Conf. Yeast Genetics Mol. Biol. 12th

16. Rine, J., Hansen, W. Hardeman, E. \& Davis, R. W. (1983) Proc. Natl. Acad. Sci. U.S.A. 80, 6750-6754 